\title{
Condiloma acuminado gigante (Tumor de Buschke-Löwenstein)
}

\author{
Miranda Aranzubía O, García Rodríguez J, González Álvarez RC, Álvarez Mújica M, \\ Rodríguez Robles L, Regadera Sejas J.
}

Servicio de Urología I. Hospital Universitario Central de Asturias. Oviedo.

\author{
Actas Urol Esp. 2008;32(9):951
}

$\mathrm{E}$ condiloma acuminado gigante de pene fue descrito por primera vez en 1955 por BuschkeLöwenstein como un tumor de crecimiento exofítico con forma de coliflor, que no degenera pero produce invasión local y destrucción de los tejidos adyacentes. Se ha relacionado con el HPV tipo 6 y 11. El diagnóstico se lleva a cabo a través de biopsia escisional y su tratamiento consiste en resección del tumor; El tratamiento con láser Nd YAG ha demostrado igualmente eficacia. En cualquier caso la recurrencia es común por lo que se hace esencial un seguimiento estricto.

Presentamos las imágenes de una lesión en un varón de 50 años, donde objetivamos un crecimiento exofitico dependiente del glande (Figs. 1 y 2). Realizamos resección de dicha lesión con posterior reconstrucción de glande más postectomía (Fig. 3). el diagnostico anatomopatológico fue de condiloma acuminado gigante de pene. Actualmente el paciente se encuentra en seguimiento sin recurrencia.

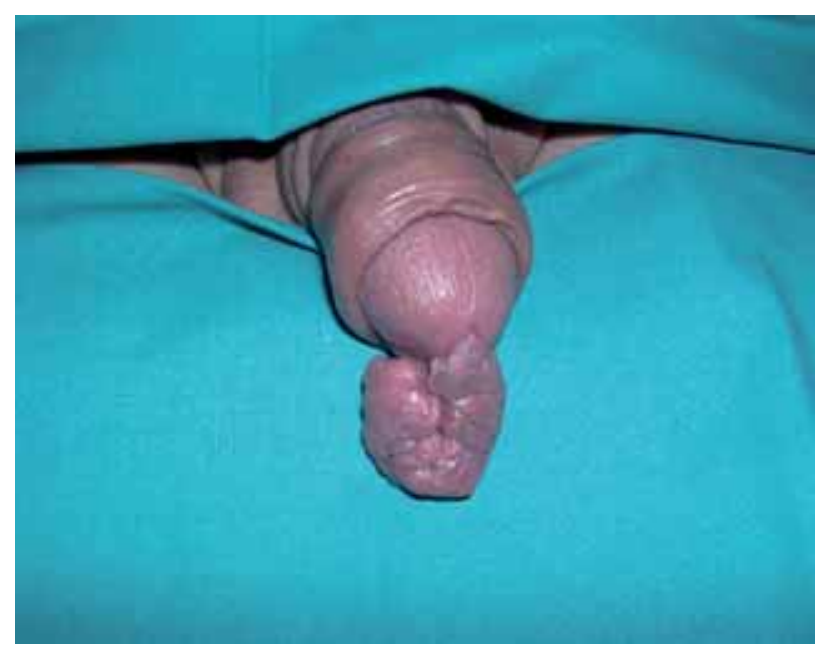

FIGURA 1. Condiloma acuminado gigante. Visión dorsal del pene.

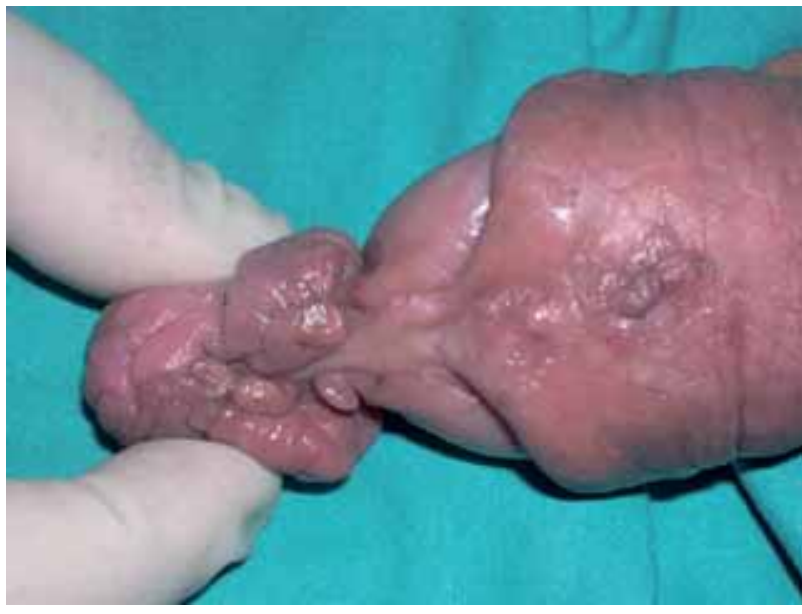

FIGURA 2. Condiloma acuminado gigante. Visión ventral del pene.

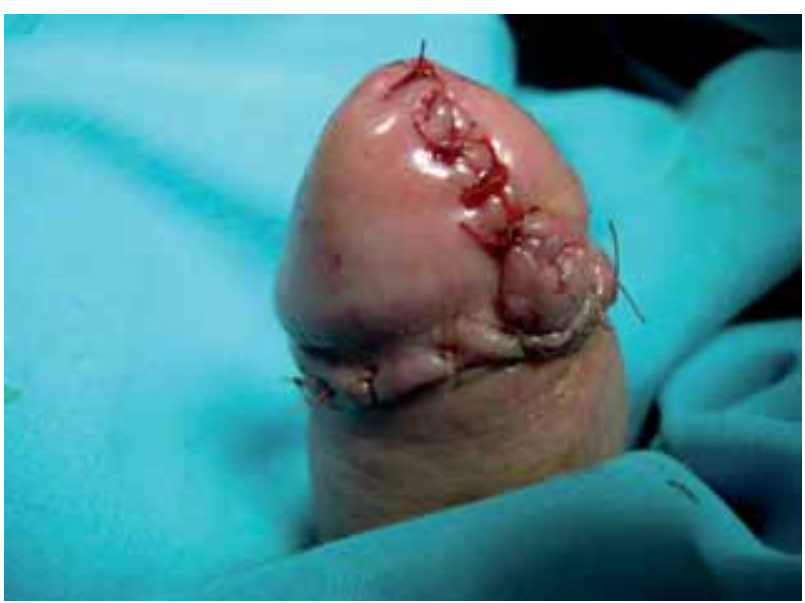

FIGURA 3. Visión ventral tras resección-reconstrucción.

Correspondencia autor: Dr. O. Miranda Aranzubía Servicio de Urología I. Hospital Universitario Central de Asturias Celestino Villamil, s/n - 33006 Oviedo (Asturias) Tel.: 985108000

E-mail autor: mirandaaranzubia@gmail.com Información artículo: Imágenes en Urología Trabajo recibido: abril 2007

Trabajo aceptado: mayo 2007 